\title{
The Global Ontology of Separation
}

\author{
Edgar Illas
}

Like alienation or commodification, separation is a figure that we have inherited from the Marxist tradition to describe the logic of capitalism. Yet in globalization this critical figure has come to define the conjuncture in more central and immediate ways. Fredric Jameson already pointed at this shift in the early 1990s when he remarked that "the logic of separation may have become even more relevant for our own period, and for the diagnosis of postmodernism, in which psychic fragmentation and the resistance to totalities, interrelation by way of difference and the schizophrenic present, and above all the systematic delegitimation described here [regarding the contemporary rejection of metadiscourses and ontological truths], all in one way or another exemplify the proteiform nature and effects of this particular disjunctive process."

In this essay I explore how separation has indeed become a structuring logic of global capitalism. I claim that whereas in modern capitalism systemic antagonisms revolved around the opposition between the separation of capital and the unity of labor, in the global world the immanent struggles over all types of separation assemble the regime of production without the dialectical opposition of labor units. Separation defines at once the main form of exploitation, the content of conflicts, and the actuality of change. I argue that for this reason, the modern model of unity, built on the project of education and Bildung, no longer embodies the possibility of individual and collective emancipation from the system. 
In globalization, separation struggles against separation itself in a self-destructive but also productive way. As a result of this internal self-referentiality, the economic logic of the system has conflated with the political disputes over lines of enmity and spaces of difference. In short, the mode of production has also become an order of global war.

\section{From Bildung to Labor to the State to Capital (and Back Again)}

Let us first examine the dialectics between unity and separation in modern capitalism. Marxism has shown how capital pursues the unification of labor and at the same time the dispersion of labor. Capital creates units of labor production but must also counteract the strength and collective power generated by these units. Michael A. Lebowitz refers to these dialectics as a contradiction between "the combination of labour as the source of social productivity and the separation of workers as the condition for their exploitation." Capital, in other words, relies on the unification of labor power, but given that this unification quickly engenders modes of resistance and class consciousness, the collective force of labor must also be kept at bay. The system draws workers together and simultaneously promotes their dispersal, since, as Karl Marx puts it, "the workers' power of resistance declines with their dispersal." ${ }^{\text {" At a structural }}$ level, these dialectics take the form of a system that conceals its own systematicity by appearing as a free, open, and nonsystematic mode of production. The system manifests and conceals itself as a nonsystem made of separate agents: autonomous entrepreneurs, free laborers, private entities, and all types of economic competitors.

A fundamental aspect is the function of education. Individual and collective formation constitute the central space to mediate the unsolvable dialectics that unify and tear apart the spheres of the social in capitalism. The birth of modern education as the practice of subjective formation-the famous Bildung - has the primary function of bridging the irreducible gap opened up by the capitalist dialectics of unification and separation.

G. W. F. Hegel's thinking on the modern subject and society in Elements of the Philosophy of Right helps us understand the mediatory function of education in modernity. For Hegel, Bildung is the process of liberation of the subjective will from particular and natural desires through the objectivity of work. Freedom is the result of the educative process by which one learns to "do everything as others do it." Freedom does not occur in some state of natural innocence, 
as with Jean-Jacques Rousseau, but instead arises through the formation of the subject as a social creature. This process of learning and socialization involves the concrete mediation of labor, which provides the moment of objective universality through which "subjective selfishness turns into a contribution towards the satisfaction of the needs of everyone else. ${ }^{55}$ But one inherent and contradictory trait defines the process of education qua labor, namely the division of labor that separates the productive work of individuals. As Hegel writes, "through this division, the work of the individual . . . becomes simpler, so that his skill at his abstract work becomes greater, as does the volume of his output." ${ }^{6}$ Thus, Bildung entails both integration and separation of subjects, both unification and division of labor.

The formulation of these dialectics aimed to contest not only the Rousseauist temptation to go back to a natural state but also the Romantic lament about the fragmentary logic of modernity. A key component of Romanticism was the condemnation of the dehumanizing effects of modern disjointedness. Friedrich Schiller's Sixth Letter on the aesthetic education of man provides a well-known enunciation of this lament. For Schiller, the spirit of utility and rationalization of modernity created the individual but also eliminated the possibility of achieving any kind of fullness: in modernity "the image of the human species is projected in magnified form into separate individuals-but as fragments." Indeed, Schiller affirms that the scope of this atomizing logic is planetary and even cosmic: "however much the world as a whole may benefit through this fragmentary specialization of human powers, it cannot be denied that the individuals affected by it suffer under the curse of this cosmic purpose."

For Schiller, the fragmentary nature of modern human beings materializes as an internal split between the sensuous drive (sinnlicher Trieb) and the formal drive (Formtrieb)..$^{9}$ For this reason, he argues that the task of education and culture must be the integration of the two drives so that each human being can "be at once conscious of his freedom and sensible of his existence." 10 This task takes place through a third drive, the play drive (Spieltrieb), whose object is the living form (lebende Gestalt) that we call aesthetic beauty. Thus, Schiller concludes that education must produce a formative aesthetic impulse (ästhetische Bildungstrieb) on which we will be able to build an "aesthetic state" as the realm of human freedom. ${ }^{11}$

In dialectical opposition to the aesthetic state, Hegel speaks of the ethical state, which must develop not from the aesthetic education of humankind but instead, as we have seen, from rational labor. Yet to what extent does Hegel suppress but also incorporate 
Schiller's aesthetic state as a basis of the ethico-political state? One would expect to find a process of Aufhebung by which aesthetics are recognized, negated, and superseded by politics. Aesthetics would thus be a negative step that leads to the construction of the state. After all, aesthetics contain an essential ontological aspect, defining not only the production of beauty but also the formative work of Bildung, based on Bild as picture, representation, creation, culture, and civilization. ${ }^{12}$

Indeed Hegel's Elements of the Philosophy of Right aims to articulate a dialectical integration of aesthetic Bild and politics. To name one example, in the section on coercion and crime in the part on abstract right, he analyzes how rightful coercion cancels and sublates the coercion of brute force. He calls the coercion of the state "pedagogical coercion, or coercion directed against savagery and barbarism [Wildheit und Rohheit]." This coercion is not properly coercive but is instead protective of the collective, or objective, freedom against "the merely natural will," which is "uncivilized [ungebildeten] will."13 Thus, the state fulfills a civilizing, "aesthetic" function that cancels and sublates the barbarism of merely subjective desires and acts.

Hegel's treatise, however, also contains symptomatic moments that reveal the problematic relationship between Bildung and politics. A few pages later in the section on rational punishment, Hegel refers to a merely subjective practice, the use of revenge, and writes that "[a]mong uncivilized [ungebildeten] peoples, revenge is undying, as with the Arabs." 14 In the section on constitutional law, he observes that the success of rational constitutions depends on the previous civilizing work of national Bildung. Hegel offers the example of the Bayonne Constitution of 1808 imposed on the Spaniards by Napoleon after he had expelled the Bourbons and appointed his brother Joseph king of Spain. This Jacobin constitution aimed to create a representative model that limited the powers of the king and the clergy but remained very unpopular among the Spaniards. Hegel attributes this unpopularity to a lack of national development: the Spaniards "rejected it [the constitution] as something alien, because they were not yet sufficiently cultivated [gebildet]."15

Hegel is not as severe with the Spaniards as he is with the Arabs, as he leaves open the possibility that further cultivation can lead to the Spaniard's rational self-consciousness. ${ }^{16}$ Despite the difference in gradation, though, the two examples point to a circular relationship between Bildung and politics. The building of the state entails a previous process of aesthetic education, and yet this formative, civilizing process is already part of the assembling of the state. In short, education is both a condition of possibility and a derivative 
effect of the state. Therefore, when Hegel blames the lack of civilization for the failure of the state in Spain or in the Arab world, he is implicitly recognizing a limit in his teleology. This limit is both logical, because statalization presupposes previous aesthetic Bildung and yet the state is precisely the agent that must develop this self-consciousness, and historical, because many peoples of the Earth have not reached and presumably will never reach the necessary conditions for their own development.

This circular interdependence between education and politics constitutes a fundamental parallax of modernity. Even though both spheres pursue unification, aesthetic education remains the site that promises the possibility of true "human" unity. And yet it is only the state that can actualize this unity by precisely confronting it with the divisions of labor and the atomizations of social production. ${ }^{17}$ To put it differently, one of the conceptual bases of modernity is the transposition of the unity provided by Bildung from culture onto labor and the state. Bildung is the condition and the effect that make possible the binding of these spheres. As Michel Espagne has written, Bildung acts as a "coincidentia oppositorum whose postulated existence makes it possible to engage in discourses on the singularity of the subject and the coherence of the group. It is certainly in this function of touchstone or interstitial glue between conceptual sets that the term Bildung is most untranslatable." 18 Thus, if labor can be the force of unification of individual and collective needs - that is, the force that brings some type of unity-in-separation between subjects and the state-this is because labor recaptures the power of Bildung and culture. As the Romantics proclaimed, this power consists in the potential to synthesize human desire and reason, freedom and logic, fragment and totality, or subject and world. In the Hegelian post-Romantic edifice, the formative power (bildende Kraft) of labor dialectically incorporates this aesthetic foundation.

But if Bildung defines these synthesizing functions in the various states of the world, then is the concept really untranslatable? Or does the untranslatability of the concept itself exemplify that the only true synthesis of culture, labor, and the state can be found in Hegel's Germanic world, that is, in civilized Europe? The genealogy of Bildung is German indeed, but the term also defines the building of any national culture or form of self-consciousness. Or, to be less positive, Bildung functions as a universal category, and yet its genealogical layers may leave non-Germanic peoples in a position of incompleteness, as we have seen with the Arabs and the Spaniards. In this respect, Bildung is not simply untranslatable; rather, it is always imperfectly translated. The imperfections 
of these translations reflect the systemic relations between each national and historical conjuncture.

Hegel's teleology of the state, however, does not equip us to understand these systemic relations. It will be Marx's nonteleological notion of the mode of production that will reveal the systemic structure of modernity. Indeed, Marx continues Hegel's focus on labor as the ontological basis of social production. Yet Marx's crucial intervention is to show that the organization of labor cannot be conceived as an internal phase of the state (the sphere of civil society) but instead is part of a mode of production that in turn determines its features and historical forms. In modernity, labor is involved in an unremitting struggle against capital-a class struggle that generates social antagonisms that are not mere stages of the state but material divisions inherent to the mode of production.

Despite Marx's theoretical shift, the dialectics between unification and separation continue to define this new inscription of labor into the representation, or Darstellung, of capitalism. It is true that in Hegel the division of labor has the positive function of configuring and unifying civil society, whereas in Marx the capitalist abstraction of labor is the source of alienation and negative separation. As he already points out in the 1844 manuscripts, this process of abstraction estranges the worker from labor in four main ways: through the relationship to the products of his labor, through the relationship to the act of production, through his own being as species-being (by turning life itself into a means for the satisfaction of needs), and through his social relationship to other human beings. ${ }^{19}$ Yet for Marx, capitalism is a dialectical machine that simultaneously generates unity and separation, creation and destruction, work and unemployment, Bildung and disintegration. Thus, Marx describes how the system of negative alienation also brings universal industriousness and the further development of human qualities: "Hence the great civilizing influence of capital; its production of a stage of society in comparison to which all earlier ones appear as mere local developments of humanity and as nature-idolatry." 20

Marx demonstrates how labor under capitalism becomes the space of exploitation and estrangement and also the space of creative formation and common struggle. Thus, while throughout Capital he tirelessly describes the miserable working conditions in factories, he occasionally also observes how the very factory system can be the site for future human development: "As Robert Owen has shown us in detail, the germ of the education of the future is present in the factory system; this education will, in the case of every 
child over a given age, combine productive labour with instruction and gymnastics, not only as one of the methods of adding to the efficiency of production, but as the only method of producing fully developed human beings." 21

Jameson points at this passage-as well as the passage about the French worker who, after having worked on a variety of jobs in San Francisco, exclaims with joy "I am fit for any sort of work, I feel less of a mollusc and more of a man"22 - as examples of Marx's dialectical representation of capitalism as both a system of exploitation and a utopian realm for creativity and change. ${ }^{23}$ For Jameson, another aspect of these systemic dialectics is the correlation between the negative process of separation and the "positive spatial phenomenon" of expansion. ${ }^{24}$ Thus, separation of labor power (from its products, from its tools, from the life of workers, and from social life altogether) finds its dialectical counterpart in the expansive drive of capital. Capitalism is a process not only of dispersal but also of transformative "metastastis and mutation." 25

These dialectical pairs, again, rely on the educative powers that accompany the exploitative divisions of capitalism. Thus, while Hegel analyzes the incorporation of Bildung into the state through the negative steps of labor and civil society, Marx shows how in fact the mediations of Bildung, labor, and the state are inscribed in a mode of production that revolves around the antagonism between capital and labor. This antagonism manifests itself in different yet interrelated forms throughout all the spheres of the social. Thus, education in capitalism brings forth the unifying project of emancipation but also functions as an ideological instrument that claims to mediate between the unbridgeable contradictions of the system.

\section{Globalization as Paroxysm and Collapse}

Globalization embodies both the paroxysmal development and the full-blown collapse of the dialectical pairs of modernity. Capitalism has taken over the planet and yet it has entered a state of unremitting crisis precisely because no further terra incognita or colonizable space is available for the expansion of a market that is already global. The transition from modernity to globalization may be interpreted as a continuation of the same systemic logics. But one impression persists: this historical shift has entailed a passage from order to disorder, from progress to messiness, from a logic of production that strives to contain its internal contradictions to a postapocalyptic situation of insurmountable chaos. 
We can understand the difference between modernity and globalization as corresponding to the two stages of capitalism devised by Marx: the stage of formal subsumption of labor under capital and the stage of real subsumption. Formal subsumption defines the incorporation into capitalism of forms of labor developed in previous modes of production. Thus, modernity constitutes the temporality of this incorporation, the dialectical temporality of the new versus the old. Real subsumption, by contrast, describes the stage in which labor is generated by capitalism itself and in which all elements of society (subjectivity, knowledge, affects, rituals) become directly productive. In this stage, as Marx writes, "general social knowledge has become a direct force of production." ${ }^{6}$ The temporality of this stage is the perpetual present of globalization. In this present, the dialectics of the old and the new give way to the spatial displacements on the immanent surfaces of the globe.

A crucial dilemma emerges in reference to the figure of separation. If in the stage of real subsumption capital and labor establish a sort of immediate correlation, then can we still conceive separation and unity as a dialectical antinomy? How must we conceive a situation in which labor is always already fused with "general social knowledge" or "general intellect," that is, if the sites of exploitation and Bildung are immediately dedifferentiated? If at a structural level the fusion of unification and separation has been fully accomplished, then have the dialectics between them become somewhat redundant?

Two main theoretical efforts by Guy Debord and by Michael Hardt and Antonio Negri have analyzed the effects of real subsumption on the logic of separation. In The Society of the Spectacle, Debord interprets the full commodification of social life in postmodernity as a stage of complete separation between humans and world. His essential point is that images are the ultimate form of the commodity as they mediate social relations and project them onto "a pseudo-world apart" in which reality can only be "apprehended in a partial way" and "as an object of contemplation." 27 Through the mediation of the image, reality is not accessible as "being" but only as "appearance," and the spectacle is the "monopolization of the realm of appearances." 28 Thus, the product of the spectacle is "separation itself" - separation of humans and world, of life and society. ${ }^{29}$ In this situation, the central role of human labor is no longer the production of commodity objects. Instead, the real work of contemporary proletarian classes is to contemplate the world spectacle that they themselves produce. Debord's analysis presents separation as a fait accompli, as a full penetration of the capitalist logic into social life through the image. The dialectics between unity and 
separation come full circle, as everyone is united by means of their separation: "The spectacle thus unites what is separate, but it unites it only in its separateness." 30

Rather than focusing on the commodity form, Hardt and Negri approach global separation in relation to political and juridical structures. They analyze the specific link between the separation of labor and the form of the state. Marx's division between formal and real subsumption allows them to historicize two moments of politico-juridical separation: the moment in which civil society mediates through separation and the moment of postcivil society, when no mediation between labor and capital is necessary. Thus, the true material function of civil society is to employ state sovereignty for the organization of labor according to the rules of capitalism. As Hardt and Negri write, "civil society is the space of the formal subsumption, the site where the state mediates, disciplines, and recuperates the social antagonisms foreign to its rule." 31

By contrast, in the stage of real subsumption, the mediation of civil society becomes unnecessary because labor is always already disciplined, so to speak. In this stage, a paradoxical gap replaces civil society. On the one hand, the real subsumption of labor under capital fuses the state and the market into the same operational entity: "the postmodern State both annuls every social power and obliges it to find meaning only in the form of the State." 32 The resulting corporate state, which Hardt and Negri later called "Empire," constitutes the commanding power that ensures the reproduction of exploitation. On the other hand, however, the lack of civil mediatory functions entails the further separation between this controlling state and the social productivity of labor or general intellect. The distance of the impervious state makes possible the full control of labor, but precisely because of this unmediated distance, labor emerges as a more autonomous space of activity.

For Hardt and Negri, the gap between capital and labor, or between the state and postcivil society, opens up a potential space to release the energies of constituent power and the project of the multitude. They propose a positive affirmation of this separation, contending that it brings forth the opportunity for a multitude of singularities to appear ("and by singularity here we mean a social subject whose difference cannot be reduced to sameness, a difference that remains different"). ${ }^{33}$ The unity of labor power is no longer a priority or even a possibility. Instead, Hardt and Negri's revolutionary directive seeks to foster plurality and further distance from the state. They call this distancing "flight and exodus." 34

Debord in turn also proposed an emancipatory route from the society of the spectacle based on distancing. The term détournement 
(diversion) defines the insurrectional operation of critiquing the present: "The defining characteristic of this use of détournement is the necessity for distance to be maintained toward whatever has been turned into an official verity." ${ }^{35}$ Thus, even if the subject that carries out this critique corresponds to "that class which is able to effect the dissolution of all classes," Debord does not exactly seek a unification of the proletariat against capitalist separation. ${ }^{36}$ As with Hardt and Negri's multitude, the emphasis is on distancing rather than on resistance or opposition.

One is tempted to say that the slogan that encapsulates these moves would no longer be "Workers of the world, unite!" but instead something like "Workers of the world, separate from separation!" Indeed, the wager of these thinkers is strictly logical: in a moment of real subsumption and full commodification, the only revolutionary path is to refuse any compromise with the system in place. In this context, even the most belligerent forms of class struggle would seem to lack any potential effectivity. For this reason, the paradigm for resistance moves toward desertion and creative escape.

The principal virtue of this paradigm shift is that it abandons the modern premise of unity. Unity, the basis for the association of workers in parties, unions, and ultimately the proletarian road to socialism, derived from the practice of education, which, as we have seen, constituted the task of emancipation but also the procedure for the disciplining of modes of labor external to capitalism. Yet in the stage of real subsumption where everyone is already "educated"-that is, where everyone is an internal part of global capitalism-it is multiplicity rather than unity that brings forth aleatory events and singular forms of change that constantly pop up in the actuality of the present. Hardt and Negri have attempted to turn this multiplicity into the subject of the multitude. But one wonders if even this gesture is still too modern, too dependent on the educative and unifying development of modern subjectivity.

Indeed, globalization has entailed a positive, unexpected effect, namely that resistance to it is also an internal event in the present. Change is not a future event in the perpetual present of the global world. Change exists here and now; it is always already taking place. The problem of conceiving resistance as separation from separation (however one wants to do so, as flight, as exodus, as improductivity, as delinking, as silence) is that there is always the risk of getting sucked back into the vertiginous spiral of the system. The system reproduces itself by reabsorbing all limits: as Marx famously put it, "capital is the endless and limitless drive to go beyond its limiting barrier. Every boundary [Grenze] is and has to be a barrier [Schranke] for it." ${ }^{37}$ Any virtual outside generates a 
boundary that can potentially reinforce the further expansion of capitalism. But when capitalism can no longer expand, then the problem of true resistance disappears too. Change pops up all the time, in irreducibly singular and unprogrammed forms.

One may immediately object that this conception of change is impossible. By definition, change cannot occur here and now. Change necessarily presupposes a difference between a present state of things and a future moment of transformation. If we get rid of the possibility of a different, "communist" future, then changes in the system coincide with the reproduction of the system, and the sites of emancipation become indistinguishable from the moments of capitalist intensification. But this is precisely the consequence of globalization: the lack of a temporal or spatial outside has determined that all thinking and action are internal to the system. The contiguity between change and reproduction is inherent to the immanence of the global world. One is tempted to say that the impossible has taken place: systemic change has become forever inseparable from the system itself.

\section{Global Politics Inc.}

A crucial consequence of this immanent relationship, or immediate dedifferentiation, between system and change is the fusion between the economic and the political logics of separation. In the real subsumption of global capitalism, where all aspects of social life generate value in direct forms, the dynamics of separation also involve a political logic.

Of course, capital has always employed the force of political enclosures and bordering. The organization of production has required concrete forms of spatialization, from the processes of primitive accumulation to the imperial and state captures of social production. ${ }^{38}$ Yet formal subsumption pursued the incorporation of external modes of labor into capitalism, and therefore the political arrangements that put into effect exploitation and colonization obeyed primarily economic reasons. The goal of formal subsumption was the Bildung of capitalism itself, so to speak, and political spaces were a superstructure that served to organize the base of the mode of production.

However, in real subsumption, the main concern for global capital is not so much the spatial unification and separation of labor. Rather, capital must respond to the instant movements of social production and readjust itself to the undulations of social workers and the general intellect. Since value is generated 
spontaneously through the very motion of social life, capital needs to identify and enclose sites of extraction of value. These operations consist in the delimitation and appropriation of productive spaces. It is for this reason that politics, understood in the strong sense as nomos, as the concrete forms of appropriation and division of Earth, or, in Schmitt's words, as "the inner measure of an original, constitutive act of spatial ordering," becomes an inherent component of the capitalist logic. ${ }^{39}$ Thus, the primary form of unity and separation is no longer the clear-cut antagonism between capital and labor but instead is the singular political divisions that perpetually reshape the spaces of globalization. In other words, the global fusion between capitalist and political logics of separation corresponds to the unmediated exploitation of social life. In this respect, the spatial formations of power that organized control and governmentality tend to be replaced by assemblages of direct violence and extraction. Ultimately, this entails the very collapse of political spacing itself, as politics and capital adopt a logic of war that blurs all stable distinctions.

One extreme and therefore paradigmatic case can illustrate the blurring between capitalist and political separation. In Israel's Occupation, Neve Gordon explains how up until the 1990s the Israeli state administered the lives of Palestinians according to "the colonization principle." The administration aimed to secure the exploitation of land, water, and labor in ways similar to any colonial context. In the last three decades, however, another principle has guided control, "the separation principle": "By separation I mean the abandonment of efforts to administer the lives of the colonized population ... while insisting on the continued exploitation of nonhuman resources (land and water). The lack of interest in or indifference to the lives of the colonized population that is characteristic of the separation principle accounts for the recent surge in lethal violence." 40

Thus, the separation principle continues to pursue the exploitation of resources but assumes no sovereign responsibility for the people. On the contrary, people become superfluous, and this superfluity connects with lethal violence in a perverse way. The state machinery that separates the people from resources and living spaces employs the violent methods that respond in turn to the violent reactions of the people, thus producing a destructive but also profitable circle between state violence and terrorism. Violence becomes a full form of employment, an economy in which the extraction of positive value coincides with the production of negative value (of death). In this way, the separation principle conflates economic production and political violence. 
Eyal Weizman also talks about "the politics of separation," or apartheid, as a "postcolonial" mode of control of Palestine, noting that this politics has entailed specific changes in military power. While previously the domination of Palestinian territories relied on military occupation, as in modern colonialism, today's governance "seeks to control the Palestinians from beyond the envelopes of their walled-off spaces, by selectively opening and shutting the different enclosures, and by relying on the strike capacity of the Air Force over Palestinian areas." ${ }^{41}$ Weizman defines this implementation of remote control as part of a "process of 'distantiation," that is, a process of detaching the various sites of antagonists. ${ }^{42}$

Indeed, distantiation probably defines the political logic of global capitalism better than separation itself. This logic corresponds to a situation of unremitting violence in which distance offers not only a form of protection but also the conditions for a concrete type of attack: the surgical intervention that strikes specific targets while intimidating entire populations. Distantiation describes the establishment of political barriers that do have not a strictly political function (that of separating friend from enemy) but a properly economic one. These barriers, which can take physical, social, virtual, and ideological forms, create violent divisions whose effects are simultaneously destructive and productive. The fabrication of endless circles of violence and the assembling and consequent expulsion of populations intensify the respatialization inherent to capitalist accumulation in the global world. In a situation in which no further territories or peoples can be colonized, the rearrangement of existing spaces constitutes the fundamental means for the (non) expansion of capital.

Indeed, expansion no longer functions extensively but instead as intensification or simply amassment. Marx already refers to this other inflection in capitalist accumulation when he describes how the permanent production of new needs goes together with the intensification of labor, an intensification that "constantly increases the circle of qualitative differences within labour (hence of surplus labour), [and] makes it more diverse, more internally differentiated." ${ }^{43}$ Marx's emphasis on differential qualities, as David Harvey and Jameson among others have taught us, enables us to analyze the logic of global capital. ${ }^{44}$ But the logic of difference perhaps corresponded to a first postmodern phase of globalization, that is, the phase of consolidation of a world market in the second half of the twentieth century. In the twenty-first century, the violence of direct extraction seems to have replaced difference as the dominant structure. In this sense, rather than intensifying difference, the production of spatial enclosures for accumulation involves the 
violence of industrial complexes of war, thus generating a permanent and endless state of global war. Capital, politics, and war constitute the three immediate aspects of the magmatic assemblages that structure the global world.

Direct and violent extraction also instantly evokes another component of Marx's analysis. Indeed, many scholars have referred to globalization as a new process of primitive accumulation. ${ }^{45}$ But one crucial difference exists between this process and the global conjuncture. Whereas primitive accumulation defines the "process of divorcing the producer from the means of production" and the producer's insertion into capitalism as wage laborer, a process that generates the dialectics between (negative) uprooting and (positive) "emancipation from serfdom," ${ }^{46}$ global enclosures of expropriation do not pursue incorporation but instead pursue expulsion. Again, Marx also already talked about expulsion when he exemplified primitive accumulation with the history of English farmers: "The last great process of expropriation of the agricultural population from the soil is, finally, the so-called 'clearing of estates,' i.e. the sweeping of human beings off them." ${ }^{47}$ Yet the expulsion of farmers, or any community, from their land pursued their incorporation into capitalism as wage laborers. By contrast, the process of advanced accumulation in globalization encloses sites and products of social life, mobilizes them as capital, and arbitrarily disposes of the populations or materials that compose them.

Or, to put it in other terms, global enclosures are not converted into private property. Instead, they release and put into movement and finally expel peoples and material and immaterial objects. These enclosures, in short, do not erect fences. For instance, Google and Facebook are paradigmatic examples of global enclosures. These platforms extract value out of the direct circulation and sharing of any imaginable thing. They do not turn materials into property and do not privatize in a classical way, yet they represent sites of colossal accumulation that also aim to expel and suppress anything that does not go through them. Another type of prevalent enclosure is the site of a disaster, whether a war or a natural catastrophe. These events serve to mobilize all types of state and nonstate agencies, media coverage, and business opportunities for insurance and real estate companies. In this way, destruction and production become part of the same logic of survival and death, protection and expulsion.

One concrete empirical practice activates the link between the amassment of capital and destruction and expulsion. Saskia Sassen has shown how this practice is financialization. Financialization produces complex instruments and algorithms that extract value by 
means of securitization, which "involves the relocation of a building, good, or debt, into a financial circuit where it becomes mobile and can be bought and sold over and over in markets near and far." 48 This process of financialization of the so-called real economy generates a large concentration of capital that results in two types of social expulsions: "for those at the bottom or in the poor middle, this means expulsion from a life space; among those at the top, this appears to have meant exiting from the responsibilities of membership in society via self-removal." ${ }^{49}$ Sassen particularly focuses on the expulsions for those at the bottom toward the "systemic edge" of the global economy. ${ }^{50}$ She examines empirical cases that illustrate various types of ejection: chronic unemployment, displacement from life spaces, eviction of people from their homes for failure to pay mortgages, ${ }^{51}$ refugee warehousing, ${ }^{52}$ expulsion due to environmental disasters, ${ }^{53}$ incarceration of surplus labor populations, ${ }^{54}$ and, not least, suicide. ${ }^{55}$

We must realize, however, that in a global system with no exteriority, expulsion constitutes another form of immanent inclusion. The expelled become productive elements precisely because they have been rendered unproductive. They can be interpreted as the global equivalent of the modern industrial reserve army: that body which, as Marx said, "belongs to capital just as absolutely as if the latter had bred it at its own cost." ${ }^{56}$ But whereas the function of the industrial reserve army was to lower the value of labor, the function of the global assemblages of the excluded is to build the spatial, political, military, and ideological separations that make these very assemblages possible. The logic is self-referential: the separation and distancing of social groups aims to extract and concentrate value by means of the violent acts of separation themselves. In a logic that mirrors the self-referential actions of finance capital, by which money creates value out of money (M-M'), the systemic logic of separation generates value out of separation itself. ${ }^{57}$

This extraction of value not only involves the war industries that enforce spatial separation, which include surveillance production, weapons, confinement, border patrolling, incarceration, cybersecurity, direct striking, and endless modes of repression and control that monopolize global politics. The key point is also that the struggle for separation becomes the central form of exploitation and domination at once. In other words, separation unleashes and at the same time contains the unbearable contradiction of a mode of production based on the financial confiscation and social removal of its own productivity. 


\section{Hyperpolitical Singularities}

If, as we saw above, systemic change and systemic reproduction coincide in the same plane of immanence, is it still possible to distinguish reactionary politics from transformative movements in the global ontology of separation? We have inherited the assumption that unity is good and separation is bad. In the struggle between capital and labor, capital instigated separation and labor pursued unity even if the dialectical relationship between the two complexified class struggle and cast doubt on the possibility of conceiving (communist) unity outside (capitalist) separation. But the immediate concurrence between economic and political separation in globalization makes it impossible to continue the proletarian projects of unification. No directives can program emancipatory pursuits of unity against exploitative forms of separation. It would be absurd to say that the erection of limits is bad and that the elimination of distinctions is good. Some limits and protectionist measures can be very uplifting, and some openings, such as transnational and military exchanges, can be very damaging. For this reason, in our global borderscape that blurs all modern distinctions, we are always engaged in singular mixtures of reproductive and transformative events. What is at stake in the present are the consequences of all forms of separation and spatial redistribution that are always already taking place. These consequences constitute the terrain of social struggle-even if, or precisely because, this is an anomic terrain, a constantly shifting topography that cannot be ordered through lines of progress or revolutionary goals.

As illustration of the present borderscape, let us finish with the singular case of the current Scottish and Catalan separatist movements. One can interpret these forms of secessionism as nationalist attempts to protect the wealth of these regions against the redistributive functions of the British and Spanish states. This interpretation is not necessarily false. But these movements generate other transformations as well. For one thing, they embody a peaceful and democratic way of founding states beyond the wars of independence, the colonial and postcolonial battles, or the ruling hegemonies of modernity. Also, they promise smaller and more flexible forms of government and locational democracy that can bring the state closer to the people. Rather than reproducing the insularity of modern nationalisms, their vocation is to articulate a different mediation between the local and the global. In fact, in the British case, the potential independence of Scotland would imply an exit from Brexit and a reconnection with the larger European space. 
This brief mention to these glocal examples should suffice to show how the struggles over separation and the redistribution of space in globalization entail both conservative and transformative consequences. Whereas in modernity the conflict between labor unity and capitalist separation provided directives on what was to be done, in the global world each struggle constitutes a singular political and economic issue in which unity and separation are constantly shifting sides and causing unanticipated effects. In this respect, unity, or unity as Bildung, no longer constitutes the single road toward emancipation. Instead, given that the anomie and spatial instability of the global world forces everyone to engage in permanent struggle, unity emerges in rapid and spontaneous ways in the course of each singular engagement. Our hyperpoliticized global existence may not give us access to emancipation, but it will continue to energize political life to its maximum expression.

\section{Notes}

1. Fredric Jameson, Postmodernism; or, The Cultural Logic of Late Capitalism (Durham, NC: Duke University Press, 1991), 399.

2. Michael A. Lebowitz, Beyond Capital: Marx's Political Economy of the Working Class (New York: Palgrave Macmillan, 2003), 87.

3. Karl Marx, Capital, Vol. 1, A Critique of Political Economy, translated by Ben Fowkes (London: Penguin, 1976), 591.

4. G. W. F. Hegel, Elements of the Philosophy of Right, edited by Allen W. Wood, translated by H. B. Nisbet (Cambridge: Cambridge University Press, 2006), 226, §187.

5. Ibid., 233, §199.

6. Ibid., 232-33, §198.

7. Friedrich Schiller, On the Aesthetic Education of Man in a Series of Letters, edited and translated by Elizabeth M. Wilkinson and L. A. Willoughby (Oxford, UK: Clarendon, 1967), 33.

8. Ibid., 43. Another classic lament is found at the end of Hölderlin's Hyperion (1799): "I can think of no people more at odds with themselves than the Germans. You see artisans, but no men, thinkers, but no men, priests, but no men, masters and servants, but no men, minors and adults, but no men-is this not like a battlefield on which hacked-off hands and arms and every other member are scattered about, while the life-blood flows from them to vanish in the sand?" Friedrich Hölderlin, Hyperion and Selected Poems, edited by Eric L. Santner (New York: Continuum, 1990, 128); also qtd. in Schiller, On the Aesthetic Education of Man in a Series of Letters, 232.

9. Schiller, On the Aesthetic Education of Man, 80-81.

10. Ibid., 95.

11. Ibid., 215. 
12. Lacoue-Labarthe and Nancy analyze how the unifying function of Bild is a key element of German Romanticism that already emerges in Kant's Third Critique. Philippe Lacoue-Labarthe and Jean-Luc Nancy, The Literary Absolute: The Theory of Literature in German Romanticism, translated by Philip Barnard and Cheryl Lester (Albany: SUNY Press, 1988), 29-37. For illuminating explanations of Bild and Bildung, see Pascal David's and Michel Espagne's entries in Dictionary of Untranslatables: A Philosophical Lexicon, edited by Barbara Cassin (Princeton, NJ: Princeton University Press, 2014), 107-21. See also Hans-Georg Gadamer's reflections in Truth and Method, translated by Joel Weinsheimer and Donald G. Marshall (London: Continuum, 2004), 8-17 and 70-77.

13. Hegel, Elements of the Philosophy of Right, 120, §93.

14. Ibid., 130, $\$ 102$.

15. Ibid., 313, $\$ 274$.

16. For other references to the question of Bildung and its lack thereof in Hegel's Elements of the Philosophy of Right, see paragraphs $\$ 107$ (in relation to brute force and natural conditions) and $\$ 150$ (in relation to individual virtue).

17. The dichotomy between aesthetic unity and social division finds its thematic correspondence in the duality between nation and state. On this correspondence, see Pheng Cheah, Spectral Nationality: Passages of Freedom from Kant to Postcolonial Literatures of Liberation (New York: Columbia University Press, 2003). See also David Lloyd and Paul Thomas's classic Culture and the State (New York: Routledge, 1998).

18. Cassin, Dictionary of Untranslatables, 111.

19. Karl Marx, Early Writings, translated by Rodney Livingstone and Gregor Benton (New York: Vintage Books, 1975), 322-34.

20. Karl Marx, Grundrisse, translated by Martin Nicolaus (New York: Penguin, 1993), 409-10, emphasis in original.

21. Marx, Capital, 614.

22. Ibid., 618 .

23. Fredric Jameson, Representing Capital: A Reading of Volume One (London: Verso, 2011), 118-19.

24. Ibid., 110 .

25. Ibid.

26. Marx, Grundrisse, 706. For formal and real subsumption, see also Marx, Capital, 1019-49.

27. Guy Debord, The Society of the Spectacle, translated by Donald Nicholson-Smith (New York: Zone Books, 1995), 12, §2.

28. Ibid., 15, §12.

29. Ibid., 21, §27.

30. Ibid., 22, §29.

31. Michael Hardt and Antonio Negri, Labor of Dionysus: A Critique of the State-Form (Minneapolis: University of Minnesota Press, 1994), 258. Hardt also points to the educational role of the mediations of civil society and the state in "The Withering of Civil Society," Social Text 45 (1995): 28-29. 
32. Hardt and Negri, Labor of Dionysus, 269.

33. Michael Hardt and Antonio Negri, Multitude: War and Democracy in the Age of Empire (New York: Penguin, 2004), 99.

34. Hardt and Negri, Labor of Dionysus, 207.

35. Debord, The Society of the Spectacle, 145, §206, emphasis in original.

36. Ibid., 154, §221.

37. Marx, Grundrisse, 334.

38. For the relationship between capital and political space, see, among many others, David Harvey, The New Imperalism (Oxford: Oxford University Press, 2003); Giovanni Arrighi, Adam Smith in Beijing: Lineages of the Twenty-First Century (London: Verso, 2007), 211-49; Sandro Mezzadra and Brett Neilson, Border as Method; or, The Multiplication of Labor (Durham, NC: Duke University Press, 2013).

39. Carl Schmitt, The Nomos of the Earth in the International Law of the Jus Publicum Europaeum, translated by G. L. Ulmen (New York: Telos, 2006), 78. As Schmitt's explains, nomos and the corresponding verb nemein refer to three simultaneous things: appropriation, division and distribution, and "pasturage" or "productive work"- "to pasture, to run a household, to use, to produce" (327). Politics as nomos includes the foundational appropriation of land, the juridical organization of this land, and the setup for the operational uses of this entity. For a conceptual analysis of nomos, see Adam Sitze, "Nomos as a Problem for Disciplinary Reason," English Language Notes 48, no. 2 (2010): 163-75.

40. Neve Gordon, Israel's Occupation (Berkeley: University of California Press, 2008), xix.

41. Eyal Weizman, Hollow Land: Israel's Architecture of Occupation (London: Verso, 2007), 11.

42. Ibid.

43. Marx, Grundrisse, 408.

44. Harvey talks about postmodern difference as the development of "special qualities". See David Harvey, The Condition of Postmodernity (Cambridge, MA: Routledge, 1990), 295-96. See also Jameson, Postmodernism, 340-56.

45. See Gavin Walker, "Primitive Accumulation and the Formation of Difference: On Marx and Schmitt," Rethinking Marxism 23, no. 3 (2011): 384-404, and the articles in The Commoner issue Enclosures, the Mirror Image of Alternatives, no. 2 (2001). Also, Harvey has renamed primitive accumulation "accumulation by dispossession" (The New Imperialism, 142-44). While this notion is key to understanding neoliberal privatization, it is not as useful for analyzing the break that supposes the central and productive role of political violence in globalization. Dispossession continues to lay the emphasis on the strictly economic logic of capital and on primitive accumulation as inherent to the system. Separation, by contrast, allows us to highlight the mixture of direct extraction and a political-spatial logic that is not imperialist, as Harvey continues to argue, but that posits an anomic spatiality of war.

46. Marx, Capital, 875.

47. Ibid., 889 . 
48. Saskia Sassen, Expulsions: Brutality and Complexity in the Global Economy (Cambridge, MA: Belknap Press of Harvard University Press, 2014), 118.

49. Ibid., 15.

50. Ibid., 218

51. Ibid., 48.

52. Ibid., 56.

53. Ibid., 62.

54. Ibid., 63.

55. Ibid., 54.

56. Marx, Capital, 784.

57. Another function of inclusive exclusion is to put into effect what I call the postbiopolitical regime of survival, which compels populations to assume a protective and entrepreneurial role toward their own survival (I examine this topic in my current book project "Global War and the Regime of Survival," manuscript in preparation). 
Copyright of Discourse: Journal for Theoretical Studies in Media \& Culture is the property of Wayne State University Press and its content may not be copied or emailed to multiple sites or posted to a listserv without the copyright holder's express written permission. However, users may print, download, or email articles for individual use. 